\title{
DAILY TIME-RESTRICTED FEEDING AND ALTERNATIVE DAY FASTING FOR WEIGHT MANAGEMENT: COMPARATIVE ANALYSIS
}

\author{
Zane Lukstiṇa, Bogdans Bodžs, and Liga Ozoliṇa-Moll \\ Faculty of Biology, University of Latvia, 1 Jelgava Str., Rīga, LV-1004, LATVIA \\ Corresponding author, zane.lukstina@lu.Iv
}

Communicated by Dace Pjanova

\begin{abstract}
The approach of limiting nutritional intake frequency, but without a large reduction of the amount of calories consumed, the so-called intermittent fasting, has gained growing popularity. Intermittent fasting is an umbrella term for meal timing schedules that cycle between voluntary fasting (or vastly reduced calories intake) and non-fasting over a defined period. In our study, we compared two of the most popular intermittent fasting regimens - 16/8 time-restricted feeding and 5/2 alternate day fasting. A total of 16 healthy young women (under 30 years of age) participated in the study, eight in each intermittent fasting group, for six consecutive weeks. Among anthropometric parameters, height, weight, umbilical waist circumference, sagittal abdominal diameter, and skinfold thickness were measured and body mass index and relative body fat were calculated. Differences between the initial values and the values after the six-week intermittent fasting period were calculated and compared between the two groups. We found no statistically significant difference ( $p>0.05$ ) between 16/8 time-restricted feeding and 5/2 alternate day fasting regimens in differences over the six-week period for the tested parameter, including weight loss. As there were no significant differences for overall changes in parameter values in the six-week period between the two intermittent fasting regimens, we concluded that both were equally suitable for weight loss programmes.
\end{abstract}

Key words: intermittent fasting, women, body fat, sagittal abdominal diameter.

\section{INTRODUCTION}

Numerous studies worldwide have proven calorie restriction to be an effective approach to regulation of body fat accumulation, but it is not always effective. In the last decade, another approach, by limiting nutritional intake frequency, but without great reduction of the amount of calories consumed - the so-called intermittent fasting - has gained growing popularity. Intermittent fasting is an umbrella term for various meal timing schedules that cycle between voluntary fasting (or vastly reduced calorie intake) and nonfasting over a given period (Patterson et al., 2015).

The various intermittent fasting regimens all have in common that they limit the amount of food consumed significantly (usually calorie intake does not exceed $25 \%$ of the daily amount needed for maintaining constant weight) or fully (no calories can be consumed) for a certain time period - certain hours per day or certain days of a week (Anton et al., 2017). The benefit of such a diet is that it is not necessary to follow the amount of food consumed and its composition very scrupulously, but instead it is required to follow certain periods of time when eating ad libitum is allowed.

Intermittent fasting has many positive effects described in the scientific literature. In addition to weight control effects, intermittent fasting also causes positive functional changes in the human body. Practicing intermittent fasting presumably induces changes in body energy metabolism, which could have a positive effect on the cardiovascular system (Mattson and Wan, 2005). This practice lowers low-density cholesterol and increases high-density cholesterol levels, lowers plasma triglyceride and inflammatory cytokine levels, stabilises arterial pressure (Sequea et al., 2012; Gotthardt et al., 2016), and stimulates lipid mobilisation from energy depot sites in adipose tissue (Mattson et al., 2017).

Intermittent fasting also helps to lower glucose levels and to prevent the development of insulin resistance and type II 
diabetes (Barnosky et al., 2014). Animal studies have shown that intermittent fasting can help to prevent the formation of malignant tumours (Lee and Longo, 2011), improve cognitive function (Li et al., 2013), and stimulate autophagic cell regeneration, including neuroprotective function (Martin et al., 2006), and has other effects.

Although there have been many studies of intermittent fasting, data comparison is complicated by the different dietary protocols used in these studies, which delays formation of common understanding in the scientific community about the effectiveness of intermittent fasting in weight management.

In our study we compared two of the most popular intermittent fasting regimens - 16/8 time-restricted feeding (16/8 TRF), where the person is allowed to consume nutrition in an eight-hour eating window followed by a 16-hour fasting period daily, and 5/2 alternate day fasting (5/2 $\mathrm{ADF}$ ), where there are two non-consecutive fasting days in a week.

The aim of the study was to evaluate which of the intermittent fasting regimens (time restricted feeding or alternate day fasting) results in more pronounced favourable changes in body weight and body composition.

\section{METHODS}

A total of 16 healthy young women participated in the study, eight in each intermittent fasting group, for six consecutive weeks. Inclusion criteria were: 18 to 30 years of age, body mass index (BMI) value in normal or overweight range $\left(18.5-29.9 \mathrm{~kg} / \mathrm{m}^{2}\right)$. Exclusion criteria were current pregnancy, self-reported metabolic diseases, and selfreported eating disorders.

Participants in the 16/8 TRF group was asked to choose a constant time of the day for the start of the 8-hour eating window followed by a 16 -hour fasting period. There was no possibility for participants to make alterations for each individual day and the schedule had to be maintained for an entire six weeks. During eating windows, participants were allowed to consume food ad libitum, but during fasting hours no food products containing calories were allowed. Participants were encouraged to drink calorie-free beverages (water, unsweetened tea, etc.) in order to maintain body water balance.

Participants in the 5/2 ADF group were asked to choose 2 non-consecutive days in a week as fasting days, where no food products containing calories were allowed. In the five remaining days of the week, participants were allowed to consume food ad libitum. The schedule was constant, without possibility for participants to make alterations for each individual week. Participants in this group also were encouraged to maintain their body water balance by intake of calorie-free drinks.

In the study, several anthropometric parameters were measured or calculated: body weight, body height, BMI, umbili- cal waist circumference, sagittal-abdominal diameter and relative body fat (calculated using the Yuhasz equation (Yuhasz, 1962) for six skinfold thickness measurement sites).

Participant weight and height were measured using a "Kern MPE” (Kern GmbH, Germany) stadiometer/scale system. BMI was calculated as body weight $(\mathrm{kg})$ divided by the square of the height $\left(\mathrm{m}^{2}\right)$.

Caliperometry was performed for six body sites using a Harpenden skinfold caliper (Gima Ltd, Italy) with a digital graduation. Triceps, suprailiac, thigh, abdominal, subscapular and medial calf skinfold thickness were measured according to the Yuhasz recommended procedure on the right side of the body, and percentage body fat was calculated using the Yuhasz equation (Yuhasz, 1962) for six skinfold measurement sites.

Umbilical waist circumference was measured using a "ADE" retractable tape measure (ADE GmbH, Germany) placed parallel to floor at the level of participants navel. Sagittal - abdominal diameter was measured using a Holtain-Kahn Abdominal Caliper (HoltainLtdUK) placed at the level of participant's $4^{\text {th }}$ lumbar vertebra with the participant in a lying position with legs extended parallel to floor.

Initial values were recorded for all anthropometric parameters, and in the following weeks values of the various parameters were obtained once per week, with the exception of relative body fat $(\mathrm{BF} \%)$ that was obtained once per every two weeks (at the beginning, after second, fourth, and sixth week of the study).

Statistical analysis was performed using MS Excel (Microsoft Corp, Redmond, WA) and SigmaPlot 14 (Systat Software, Inc). Data are presented as mean \pm standard deviation (SD). The absolute difference and percentage difference between the initial values and the final values were calculated and compared between the two study groups. Significant differences between initial and final parameter values within study groups were calculated using the paired Student's t-test or Wilcoxon signed-rank test, and between study groups using the Student's t-test or Mann-Whitney rank sum test. A $p$ value 0.05 was considered statistically significant.

The study was approved by the Ethical Committee of the Institute of Cardiology and Regenerative Medicine, University of Latvia (No. 179/2019; effective from 21.08.2019) and the participants signed a statement of awareness and voluntary participation.

\section{RESULTS}

At the beginning of the study, the average BMI, which characterises body weight according to height, was considered to be normal body weight in both groups: $23.70 \pm 2.21$ $\mathrm{kg} / \mathrm{m}^{2}$ for the $16 / 8 \mathrm{TRF}$ group and $25.12 \pm 3.31 \mathrm{~kg} / \mathrm{m}^{2}$ for the $5 / 2$ ADF group (Table 1 ). There was no significant dif- 
Table 1. Initial values of anthropometric parameters for both study groups

\begin{tabular}{lcc}
\hline & $16 / 8 \mathrm{TRF}$ & $5 / 2 \mathrm{ADF}$ \\
\hline Age, years $\pm \mathrm{SD}$ & $23.87 \pm 2.95$ & $25.12 \pm 3.31$ \\
Height, $\mathrm{m} \pm \mathrm{SD}$ & $1.67 \pm 0.07$ & $1.68 \pm 0.05$ \\
Weight, $\mathrm{kg} \pm \mathrm{SD}$ & $66.36 \pm 9.58$ & $62.49 \pm 5.02$ \\
$\mathrm{BMI}, \mathrm{kg} / \mathrm{m}^{2} \pm \mathrm{SD}$ & $23.70 \pm 2.21$ & $22.22 \pm 1.09$ \\
$\mathrm{BF} \% \pm \mathrm{SD}$ & $24.74 \pm 7.64$ & $23.51 \pm 4.26$ \\
$\mathrm{UWC}, \mathrm{cm} \pm \mathrm{SD}$ & $78.31 \pm 7.07$ & $77.19 \pm 7.11$ \\
$\mathrm{SAD}, \mathrm{cm} \pm \mathrm{SD}$ & $17.46 \pm 1.86$ & $16.75 \pm 1.23$
\end{tabular}

BMI, body mass index; BF\%, relative body fat; UWC, umbilical waist circumference; SAD, sagittal abdominal diameter; 16/8 TRF, alternate day fasting group; 5/2 ADF, time-restricted feeding group

ference $(p>0.05)$ in the anthropometric parameters between the study groups. Therefore, the groups were considered to be comparable for initial anthropometric parameters.

Changes in anthropometric parameters during the six-week study period from the initial values in absolute and relative units are shown in Table 2 for both groups.

Statistically significant $(p<0.05)$ weight loss for the study participants in both groups were observed from the third week of the study period. Total weight loss during the whole study period for the 16/8 TRF group was on average $1.97 \mathrm{~kg}(2.85 \%$ of the initial weight). For the $5 / 2 \mathrm{ADF}$ group, weight loss was $1.78 \mathrm{~kg}$, or $2.70 \%$ of mean initial weight. The same pattern was observed for BMI, as BMI is dependent on weight and height, the latter of which did not change during the study period. A statistically significant difference in weight change between the study groups was not found $(p>0.05)$.

Despite the minimal difference of weight loss between the two groups, the difference in final values of relative body fat $\mathrm{BF} \%$ seemed to be more pronounced. $\mathrm{BF} \%$ decreased by $1.32 \%$ for the $16 / 8$ TRF group and by $2.35 \%$ for the $5 / 2$ ADF group. The change of $\mathrm{BF} \%$ was $78 \%$ greater for the $5 / 2$ ADF group compared to the 16/8 TRF group. Nevertheless, this difference was not statistically significant $(p>$ $0.05)$.

Although reduction of relative body fat was typical for most participants within both groups, it should be highlighted that trends in body fat changes for participants differed considerably. Among the two groups, reduction of relative body fat was observed for $69 \%$ of participants, while increase in relative body fat occurred for $1 / 4^{\text {th }}$ of the participants. There was no change in relative body fat for one participant in the study.

Relative body fat changes for the 16/8 TRF group are shown in Figure 1: Figure 1 (left) shows the proportion of participants who had decreased relative body fat, no change in relative body fat and increase in relative body fat. Figure 2 (right) shows changes in relative body fat for individual participants during the study as a per cent change of the initial value as a reference point.

Table 2. Absolute and relative changes of mean anthropometric parameters values during six weeks of the study period

\begin{tabular}{|c|c|c|c|c|c|c|c|c|c|c|c|c|c|}
\hline & & After 1 & week & After 2 & I week & After 3 & I week & After 4 & 1 week & After 5 & week & After 6 & 1 week \\
\hline & & $\begin{array}{c}\text { Absolute } \\
\text { unit }\end{array}$ & $\%$ & $\begin{array}{c}\text { Absolute } \\
\text { unit }\end{array}$ & $\%$ & $\begin{array}{c}\text { Absolute } \\
\text { unit }\end{array}$ & $\%$ & $\begin{array}{c}\text { Absolute } \\
\text { unit }\end{array}$ & $\%$ & $\begin{array}{c}\text { Absolute } \\
\text { unit }\end{array}$ & $\%$ & $\begin{array}{c}\text { Absolute } \\
\text { unit }\end{array}$ & $\%$ \\
\hline Weight, & $16 / 8$ & -0.35 & -0.59 & -1.00 & -1.50 & -1.42 & -2.08 & -1.56 & -2.24 & -1.92 & -2.71 & -1.97 & -2.85 \\
\hline & TRF & \pm 0.75 & \pm 1.14 & \pm 0.70 & \pm 1.06 & \pm 0.95 & \pm 1.38 & \pm 1.21 & \pm 1.80 & \pm 1.56 & \pm 2.16 & \pm 1.32 & \pm 1.90 \\
\hline & $5 / 2$ & -0.55 & -0.84 & -1.00 & -1.55 & -0.96 & -1.43 & -1.50 & -2.29 & -1.55 & -2.31 & -1.78 & -2.70 \\
\hline & $\mathrm{ADF}$ & \pm 0.98 & \pm 1.59 & \pm 1.09 & \pm 1.74 & \pm 1.63 & \pm 2.65 & \pm 1.45 & \pm 2.20 & \pm 1.83 & \pm 2.77 & \pm 1.80 & \pm 2.77 \\
\hline BMI, & $16 / 8$ & -0.14 & -0.59 & -0.35 & -1.50 & -0.50 & -2.08 & -0.54 & -2.24 & -0.66 & -2.71 & -0.69 & -2.85 \\
\hline $\mathrm{kg} / \mathrm{m}^{2}$ & TRF & \pm 0.27 & \pm 1.14 & \pm 0.24 & \pm 1.06 & \pm 0.33 & \pm 1.38 & \pm 0.42 & \pm 1.80 & \pm 0.52 & \pm 2.16 & \pm 0.45 & \pm 1.90 \\
\hline & $5 / 2$ & -0.20 & -0.84 & -0.35 & -1.55 & -0.34 & -1.43 & -0.53 & -2.29 & -0.53 & -2.31 & -0.62 & -2.70 \\
\hline & $\mathrm{ADF}$ & \pm 0.36 & \pm 1.59 & \pm 0.39 & \pm 1.74 & \pm 0.59 & \pm 2.65 & \pm 0.51 & \pm 2.20 & \pm 0.64 & \pm 2.77 & \pm 0.63 & \pm 2.77 \\
\hline UWC, & $16 / 8$ & -1.19 & -1.51 & -2.50 & -3.21 & -3.31 & -4.20 & -3.56 & -4.47 & -3.63 & -4.46 & -2.75 & -3.45 \\
\hline $\mathrm{cm}$ & TRF & \pm 0.75 & \pm 1.00 & \pm 1.28 & \pm 1.61 & \pm 1.77 & \pm 2.13 & 2.50 & \pm 3.01 & \pm 3.25 & \pm 4.03 & \pm 3.80 & \pm 4.73 \\
\hline & $5 / 2$ & -1.44 & -1.74 & -2.25 & -2.76 & -2.19 & -2.62 & -1.91 & --2.24 & -1.71 & -1.98 & -0.50 & -0.41 \\
\hline & $\mathrm{ADF}$ & \pm 1.61 & \pm 1.96 & \pm 1.91 & \pm 2.16 & \pm 2.58 & \pm 3.05 & \pm 3.09 & \pm 3.75 & \pm 2.93 & \pm 3.40 & \pm 3.85 & \pm 4.51 \\
\hline SAD, & $16 / 8$ & -0.41 & -2.35 & -0.34 & -2.11 & -0.25 & -1.46 & -0.26 & -1.45 & -0.53 & -2.92 & -0.99 & -5.57 \\
\hline $\mathrm{cm}$ & TRF & \pm 0.75 & \pm 4.28 & \pm 0.89 & \pm 5.11 & \pm 0.68 & \pm 4.29 & \pm 0.77 & \pm 4.54 & \pm 0.89 & \pm 5.29 & \pm 0.62 & \pm 3.42 \\
\hline & $5 / 2$ & 0.01 & 0.12 & -0.05 & -0.22 & -0.33 & -1.89 & -0.49 & -2.82 & -0.58 & -3.21 & -0.55 & -3.12 \\
\hline & $\mathrm{ADF}$ & \pm 0.52 & \pm 3.19 & \pm 0.65 & \pm 3.81 & \pm 0.46 & \pm 2.75 & \pm 0.74 & \pm 4.28 & \pm 0.89 & \pm 5.27 & \pm 0.87 & \pm 5.00 \\
\hline BF\%, & $16 / 8$ & & & -0.09 & 0.80 & & & -1.01 & -2.41 & & & -1.32 & -4.17 \\
\hline$\%$ & TRF & & & \pm 1.60 & \pm 6.92 & & & \pm 2.41 & \pm 10.39 & & & \pm 3.11 & \pm 12.44 \\
\hline & $5 / 2$ & & & -0.15 & -0.20 & & & -1.99 & -7.98 & & & -2.35 & -8.92 \\
\hline & $\mathrm{ADF}$ & & & \pm 1.42 & \pm 6.56 & & & \pm 2.47 & \pm 10.47 & & & \pm 2.57 & \pm 11.71 \\
\hline
\end{tabular}

Weight, $\mathrm{kg}$; BMI, body mass index, $\mathrm{kg} / \mathrm{m}^{2}$; UWC, umbilical waist circumference, $\mathrm{cm}$; SAD, sagittal abdominal diameter, $\mathrm{cm}$; BF\%, relative body fat, \%; 16/8 TRF, alternate day fasting group; 5/2 ADF, time-restricted feeding group 

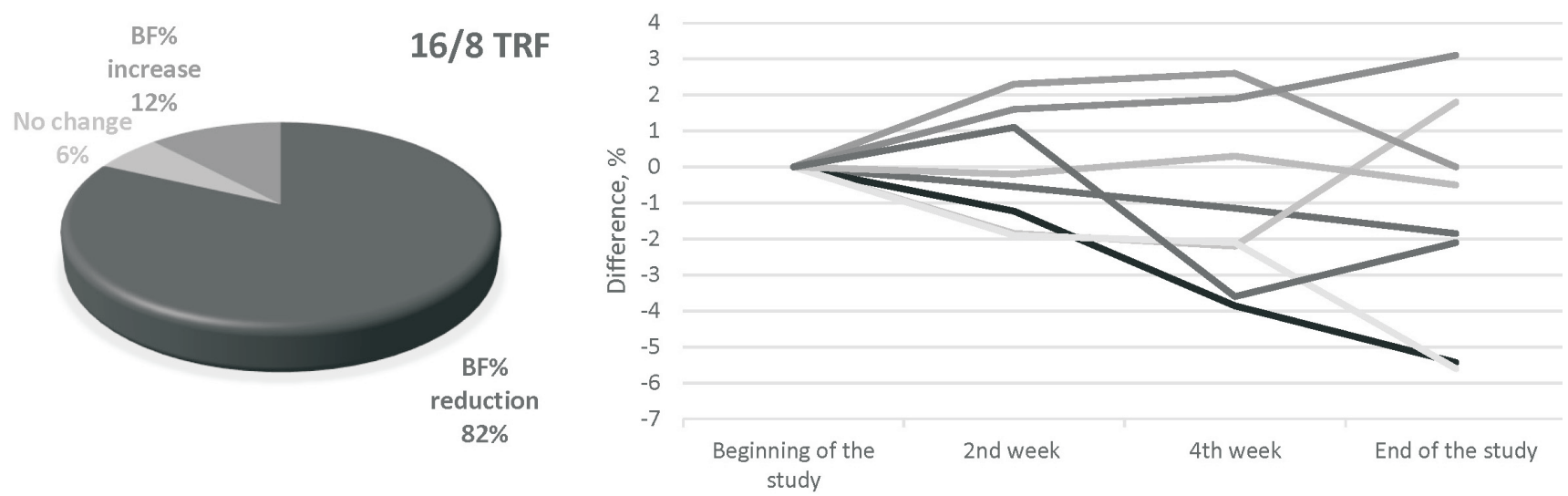

Fig. 1. Changes of relative body fat of the 16/8 TRF group. Left - percentage distribution of participants with different relative body fat outcome compared to baseline values; right - trends of relative body fat changes for individual participants.
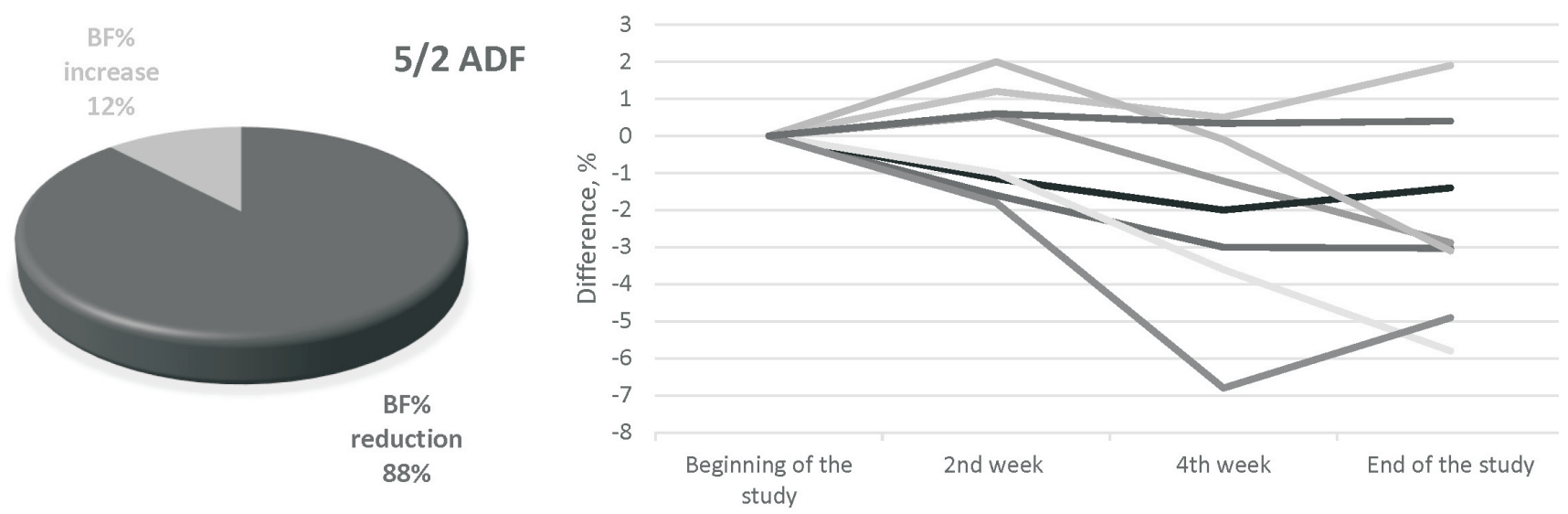

Fig. 2. Changes of relative body fat of the $5 / 2 \mathrm{ADF}$ group. Left - percentage distribution of participants with different relative body fat outcome compared to baseline values; right - trends of relative body fat changes for individual participants.

As shown in Figure 1, five participants from the 16/8 TRF group showed a decrease of relative body fat, one participant showed no change in relative body fat, while two women showed an increase in relative body fat. Given the large scatter of the data, no statistically significant difference was observed between the initial and final relative body fat values $(p<0.05)$.

Figure 2 displays body fat changes for the 5/2 ADF group. Figure 2 (left) shows the distribution of participants who had an increase or decrease of relative body fat. Figure 2 (right) shows trends of changes in relative body fat for individual participants during the study, taking the initial value as a reference point.

As shown in Figure 2, relative body fat decreased for six participants from the 5/2 ADF group, and increased for two women. Given the large scatter of the data, no statistically significant difference was observed between the initial and final relative body fat values $(p>0.05)$ also in this group.

Other anthropometric parameters examined in the current study, such as umbilical waist circumference and sagittal abdominal diameter, showed no statistically significant difference between the values at the beginning and at the end of the six-week study period in both study groups. Also, there was no statistically significant difference in the changes in these parameters between both study groups (in both cases $p>0.05$ ).

\section{DISCUSSION}

A total of eighteen participants began the study, but two did not complete the study, which was a drop-out rate of $11 \%$. Other authors previously have reported variable results regarding drop-out rate. Data available in the scientific literature suggest that for alternate day fasting the rate varies from less than 12\% (Bhutani et al., 2013; Harvie et al., 2013; Varandy et al., 2013) to more than 35\% (Keogh et al., 2014; Trepakowski et al., 2017), being on average around 20\% (Rothschild et al., 2014). Although it should be noted that the sample size in our study was rather small, there was a rather low drop-out rate. This can be partly explained by the relatively short duration of our study, as longer studies usually tend to have higher drop-out rates.

As with alternate day fasting, it has been previously reported that drop-out rates for time restricted feeding also vary over a relatively large range from about $5 \%$ (Kesztyüs 
et al., 2019) to $26 \%$ (Gabel et al., 2018) and more. Drop-out rates in TRF studies, compared to ADF studies, are smaller and on average about $10 \%$ (Rothschild et al., 2014). This coincides with our result.

Weight changes during the study showed statistically significant differences $(p<0.05)$ between initial and final values for each of the study groups. These results are consistent with the results of other authors, who have also observed this relationship (for a recent review see Welton et al., 2020). However, there was no significant difference between the two groups in the parameters studied $(p>0.05)$.

It is widely accepted that weight is lost faster at the beginning of dietary intervention, but during the dietary intervention, the metabolic rate gradually slows down because of adaptive mechanisms, or the so-called starvation response, which tends to maintain the body energy reserves (Heilbronn et al., 2006; Steinhauser et al., 2018). We did not observe such a pattern in our study. One of the reasons for this could be that there were no strict rules for the amount of calorie consumption for participants, while requirements were made only for the eating schedule. The participants were able to make up for the calories deficit arising on fasting hours or days in the feasting hours or days, when ad libitum food consumption was allowed. A shortcoming of our study design was a lack of data on energy intake during the study period. In future studies it would be necessary to monitor participant calorie intake to gain a better understanding of calorie deficit.

Change in relative body fat $\mathrm{BF} \%$ is recognised as a better indicator for characterising weight loss compared to weight reduction, because it is well known that weight reduction during dietary intervention is associated not just with loss of fat mass, but also with loss of muscle mass (Janssen and Ross, 1999). Both study groups showed similar and statistically significant $(p<0.05)$ weight loss, while the difference in change of $\mathrm{BF} \%$ between the groups was not statistically significant $(p>0.05)$. This can be explained by the large scatter of data due to increase of relative body fat for some participants $(6 \%)$, no decrease in in $25 \%$, and decrease in $69 \%$

BF\% measured with caliperometry estimates only the percentage of subcutaneous fat, but does not characterise visceral fat depots. To overcome this limitation, we introduced two other parameters in our study - umbilical waist circumference and sagittal abdominal diameter. While the difference in these mentioned parameters was noticeable between the groups, it was not statistically significant $(p>$ 0.05 ) both between initial and final values within each group, as well as compared between both groups. Thus, the amount of visceral fat did not significantly change and differ between the groups $(p>0.05)$.

In this pilot study we gained several valuable lessons for future studies. Firstly, overweight and/or obese subjects need to be enrolled, because normal weight subjects do not benefit much from dietary intervention regarding weight and fat loss, as their weight already is considered to healthy. Also, calorie counting throughout the whole study is necessary, in order to be able to draw reasonable conclusions about the extent of the energy deficit in each group and for each participant. It even may be useful to go a step further and ensure that weekly consumed calories, despite the regime followed, should be fixed, and personalised for each participant. Also, it is important that the time course of the study should be extended, because currently the most significant lack of information is for intermittent fasting dietary intervention that is longer than three months.

\section{CONCLUSIONS}

Short duration intermittent fasting for six-week time period did not result in statistically significant differences in changes of anthropometric parameters used to characterise weight and body fat accumulation in study participant groups with different intermittent fasting regimens - alternate day fasting and time restricted feeding. Thus, we conclude that the two studied fasting regimens are equally suitable for weight management purposes.

\section{ACKNOWLEDGEMENTS}

This research was supported by the University of Latvia research priority "Public Health, Quality of Life and $\mathrm{Na}$ tional Sustainability" by the research grant "Evaluation of the Risk of Metabolic Malignant Obesity and its Reduction Possibilities in the Young Adults' Population"; grant number ZD2016/AZ110.

\section{REFERENCES}

Anton, S. D., Moehl, K., Donahoo, W. T., Marosi, K., Lee, S. A., Mainous, A. G., Leeuwenburgh, C., Mattson, M. P. (2017). Flipping the metabolic switch: Understanding and applying the health benefits of fasting. Obesity, 26 (2), 254-268.

Barnosky, A. R., Hoddy, K. K., Unterman, T. G., Varady, K. A. (2014). Intermittent fasting vs daily calorie restriction for type 2 diabetes prevention: A review of human findings. Translat. Res., 164 (4), 302-311.

Bhutani, S., Klempel, M. C., Kroeger, C. M., Trepanowski, J. F., Varady, K. A. (2013). Alternate day fasting and endurance exercise combine to reduce body weight and favorably alter plasma lipids in obese humans. Obesity, 21, 1370-1379.

Gabel, K., Hoddy, K. K., Haggerty, N., Song, J., Kroeger, C. M., Trepanowski, J. F., Panda, S., Varady, K. A., (2018). Effects of 8-hour time restricted feeding on body weight and metabolic disease risk factors in obese adults: A pilot study. Nutr. Healthy Aging, 4 (4), 345-353.

Gotthardt, J. D., Verpeut, J. L., Yeomans, B. L., Yang, J. A., Yasrebi, A., Roepke, T. A., Bello, N. T. (2016). Intermittent fasting promotes fat loss with lean mass retention, increased hypothalamic norepinephrine content, and increased neuropeptide $\mathrm{Y}$ gene expression in diet-induced obese male mice. Endocrinology, 157 (2), 679-691.

Harvie, M., Wright, C., Pegington, M., McMullan, D., Mitchell, E., Martin, B., Cutler, R. G., Evans, G., Whiteside, S., Howell, A. et al. (2013). The effect of intermittent energy and carbohydrate restriction v. daily energy restriction on weight loss and metabolic disease risk markers in overweight women. Brit. J. Nutr., 110, 1534-1547. 
Heilbronn, L. K., de Jonge, L., Frisard, M. I., DeLany, J. P., Larson-Meyer, D. E., Rood, J., Nguyen, T., Martin, C. K., Volaufova, Most, M. M., et al. (2006). Effect of 6-month calorie restriction on biomarkers of longevity, metabolic adaptation, and oxidative stress in overweight individuals: A randomized controlled trial. JAMA, 295 (13), 1539-1548.

Janssen, I., Ross, R. (1999). Effects of sex on the change in visceral, subcutaneous adipose tissue and skeletal muscle in response to weight loss. Int. J. Obes. Rel. Metab. Disord., 23 (10), 1035-46.

Keogh, J. B., Pedersen, E., Petersen, K. S., Clifton, P. M. (2014). Effects of intermittent compared to continuous energy restriction on short-term weight loss and long-term weight loss maintenance. Clin. Obes., 4, $150-156$.

Kesztyüs, D., Cermak, P., Gulich, M., Kesztyüs, T. (2019). Adherence to time-restricted feeding and impact on abdominal obesity in primary care patients: Results of a pilot study in a pre-post design. Nutrients, 11 (12), 2854.

Lee, C., Longo, V. D. (2011). Fasting vs dietary restriction in cellular protection and cancer treatment: From model organisms to patients. Oncogene, 30 (30), 3305-3316.

Li, L., Wang, Z., Zuo, Z. (2013). Chronic intermittent fasting improves cognitive functions and brain structures in mice. PLOS ONE, 8 (6), e66069.

Martin, B., Mattson, M. P., Maudsley, S. (2006). Caloric restriction and intermittent fasting: Two potential diets for successful brain aging. Ageing Res. Rev., 5 (3), 332-353

Mattson, M. P., Longo, V. D., Harvie, M. (2017). Impact of intermittent fasting on health and disease processes. Ageing Res. Rev., 39, 46-58.

Mattson, M., Wan, R. (2005). Beneficial effects of intermittent fasting and caloric restriction on the cardiovascular and cerebrovascular systems. $J$. Nutr. Biochem., 16 (3), 129-137.
Patterson, R. E., Laughlin, G. A., Sears, D. D., LaCroix, A. Z., Marinac, C., Gallo, L. C., Hartman, S. J., Natarajan, L., Senger, C. M., Villaseńor, A. et al. (2015). Intermittent fasting and human metabolic health. J. Acad. Nutr. Diet., 115 (8), 1203-1212.

Rothschild, J., Hoddy, K. K., Jambazian, P., Varady, K. A. (2014). Time-restricted feeding and risk of metabolic disease: A review of human and animal studies. Nutr. Rev., 72 (5), 308-318.

Sequea, D. A., Sharma, N., Arias, E. B., Cartee, G. D. (2012). Calorie restriction enhances insulin-stimulated glucose uptake and Akt phosphorylation in both fast-twitch and slow-twitch skeletal muscle of 24-month-old rats. $J$. Gerontol. A Biol. Sci. Med. Sci., 67 (12), 1279-1285.

Steinhauser, M. L., Olenchock, B. A., O'Keefe, J., Lun, M., Pierce, K. A., Lee, Pantano, L., Klibanski, A., Shulman, G. I., H., Fazeli, P. K. et al. (2018). The circulating metabolome of human starvation. JCI Insight, 3 (16), 121434.

Trepanowski, J. F., Kroeger, C.M., Barnosky, A., Klempel, M.C., Bhutani, S., Hoddy, K.K., Gabel, K., Freels, S., Rigdon, J., Varady, K. A. et al. (2017). Effect of alternate-day fasting on weight loss, weight maintenance, and cardioprotection among metabolically healthy obese adults: A randomized clinical trial. JAMA Int. Med., 177 (7), 930-938.

Varady, K. A., Bhutani, S., Klempel, M. C., Kroeger, C. M., Trepanowski, J. F., Haus, J. M., Hoddy, K. K., Calvo, Y. (2013). Alternate day fasting for weight loss in normal weight and overweight subjects: A randomized controlled trial. Nutr. J., 12, 146.

Welton, S., Minty, R., O'Driscoll, T., Willms, H., Poirier, D., Madden, S., Kelly, L. (2020). Intermittent fasting and weight loss: Systematic review. Canad. Fam. Phys., 66 (2), 117-125.

Yuhasz, M. S. (1962). The Effects of Sports Training on Body Fat in Man with Prediction of Optimal Body Weight. Doctoral dissertation. University of Illinois, Urbana, Illinois, USA. 128 pp.

Received 29 December 2021

Accepted in the final form 1 February 2022

\section{INTERVĀLĀ BADOŠANĀS SVARA KONTROLEI: DAŽĀDU REŽĪMU EFEKTIVITĀTES SALĪDZINĀJUMS}

Arvien pieaugošu popularitāti pasaulē iegūst uztura režīms, kas ierobežo nevis ar ēdienu uzṇemto enerǵijas daudzumu, bet gan ēdiena uzņemšanas laika intervālu — tā sauktā intervālā badošanās. Intervālā badošanās ir termins, ar ko raksturo dažādus ēdienreižu grafikus, kuriem kopīga iezīme ir brīvprātīga badošanās noteiktā laika posmā (vai arī ievērojami samazināta kaloriju daudzuma uzṇemšana), kas mijas ar neierobežotu ēdiena uzṇemšanu. Mūsu pētījumā tiek salīdzināti divi populārākie intervālās badošanās režīmi — 16/8 laikā ierobežota uztura uzṇemšana un 5/2 alternatīvo dienu badošanās. Sešu nedēḷ ilgā pētījumā piedalījās 16 praktiski veselas, jaunas sievietes (līdz 30 gadu vecumam), astonas katrā intervālās badošanās grupā. Tika noteikti un analizēti vairāki antropometriskie parametri (augums, svars, vidukḷa apkārtmērs nabas līmenī, sagitālais abdominālais diametrs), kā arī aprēķināts ķermeņa masas indekss un relatīvais tauku daudzums. Tika aprēḳinātas un salīdzinātas noteikto antropometrisko un no tiem aprēkināto parametru vērtību atšḳirības pētījuma gaitā abās grupās, kā arī veikts statistisks parametru salīdzinājums starp abu grupu vērtībām. Statistiski būtiska atškirība starp 16/8 laikā ierobežotas uztura uzṇemšanas un $5 / 2$ alternatīvo dienu badošanās režīmu grupām starp sākotnējām vērtībām un pētījuma beigu vērtībām netika konstatēta $(p>0.05)$. Tā kā parametru vērtību kopējās izmainas sešu nedēḷu laikā starp abiem intervālās badošanās režīmiem nav būtiskas, mēs secinām, ka abi intervālās badošanās uztura režīmi ir vienlīdz piemēroti svara regulēšanas mērkiem. 